\title{
Goat Rearing: A Pathway for Livelihood Security of Farm Women
}

\author{
Barkha Sharma $^{1 *}$, Jagdish Patidar ${ }^{2}$, D.R. Pachauri ${ }^{3}$ and Sarvesh Tripathy ${ }^{4}$ \\ Krishi Vigyan Kendra Jaora, Ratlam (M.P), India \\ *Corresponding author
}

\begin{tabular}{|c|}
\hline Keywords \\
\hline $\begin{array}{l}\text { Milk production, } \\
\text { Mineral mixture } \\
\text { supplement }\end{array}$ \\
\hline Article Info \\
\hline $\begin{array}{l}\text { Accepted: } \\
07 \text { November } 2018 \\
\text { Available Online: } \\
10 \text { December } 2018\end{array}$ \\
\hline
\end{tabular}

\section{A B S T R A C T}

Goat rearing plays a prominent role in the rural economy in supplementing the income of rural household particularly the landless, marginal and small farmers. Goat is considered as poor man's cow and it can be profitably being reared with low investment under semiintensive as well as the extensive systems of management. They provide quick return on account of their short generation intervals, high rate of prolificacy and making the related products. Goat's importance is indicated by various functional contributions like milk, meat, skin, socio-economic relevance security, income generation, human nutrition and stability of farming system. Krishi Vigyan Kendra have been playing a vital role in transfer of technology, technology dissemination of information to improve animal productivity, income, knowledge and empowering farm women. Improvement in livestock production is, therefore, an important pathway for increasing the income of farm women and landless laborers give the uncertainties of crop production. In this term Krishi Vigyan KendraJaora, Ratlam conduct demonstrations during 2015-16 to 2017-18 to assess the income generation of farm women through goat rearing to find out the response of mineral mixture and concentrate feeding. The experiment shows average (90 days) highest milk yield (4174.6 g) during 2016-17, per day average highest milk yield $580.2 \mathrm{~g}$ (34.3\%) was increased by feeding of mineral mixture.

\section{Introduction}

India is a home of 18 per cent of world goat population (FAO, 2015). India is the largest producer of goat milk $(4.85 \mathrm{Mt})$ and second largest producer of goat meat $(0.6 \mathrm{Mt})$. Goat meat alone contributes about 54 per cent to the total value of output from the goat sector. The goat-rearing in India is widespread and is largely concentrated among resource- poor households which are landless or have tiny pieces of land. Households cultivating less than 2.0 ha land (marginal and small) are the custodian of more than 76 per cent of the total goats in the country (GoI, 2006-07). Therefore, goat-rearing has one of the most inclusive growth rates among all the livestock species (Singh et al., 2013). Demographic changes in livestock population in the country have also shown a shift that favour small ruminants, particularly goats (Dikshit et al., 2012).

Milk and milk production are the essential food items of human beings which provide sufficient nutritional supplements especially to 
the children. The milk production in the country has increased from 146.3 million tones in 2014-15 to $155.5 \mathrm{mt}$ in 2015-16 registering a growth of $6.27 \%$. Also, the per capita availability has increased from $225 \mathrm{~g}$ per day in 2003-04 to $337 \mathrm{~g}$ per day in 201516.(NAP-2022) (Table 1).

Goat, in true sense, is called as poor man's cow due to its tremendous economic importance in contributing milk, meat, household nutrition security and livelihood to the poor people. Goat can consume a variety of vegetation, which are not useful for other species of livestock (Tanwar, 2011).

Goats contribute significantly to the India economy by sustaining livelihood and supplementing Income of small farmers and rural poor's. The demand for goat meat is progressively increasing as Indian prefers goat meat (Chevon) among all other meats (Sen et al., 2004). The value of the output from goat milk and meat was estimated as Rs. 44.3 billion and Rs. 71.66 billion, respectively during 2004-05 (GOI, 2006). India possesses 16.60 per cent (124.50 million) of the world goat population and rank first in world (Singh, 2004).

Goats play an important role in the food and nutritional security of the rural poor especially in the rainfed regions where crop production is uncertain, and rearing large ruminants is restricted by acute scarcity of feed and fodder. Goat rearing has distinct economic and managerial advantages over other livestock because of its less initial investment, low input requirement, higher prolificacy, early sexual maturity, and ease in marketing. Goats can efficiently survive on available shrubs and trees in unfavourable environments. In pastoral societies in India, goats are kept as a source of additional income and as an insurance against income shocks of crop failure (Kumar, 2010).
In addition, the rural poor who cannot afford to maintain a cow or a buffalo find goat as the best alternative source of supplementary income and milk. This is one reason why poor rural households maintain a few number of goats. Unlike a cow or buffalo, a few goats can be maintained easily and can be easily liquidated in times of distress. In recent years, goat enterprise has also shown promise of its successful intensification and commercialisation (Kumar, $2007 \mathrm{a}, \mathrm{b}$ ).

Goat meat, milk and by-products provide important nutritional components of a human diet.Goat milk and dairy products are also a major source of protein, as well as calcium in the human diet. Due to its smaller fat globules, goat milk is easier to digest than cow milk and is good for babies, children and adults. Calcium is an important mineral that strengthens bones and teeth. One liter of goat milk per day can provide:

All the protein a child needs to age 6 60 per cent of the protein a child needs to age 14

Half the protein a child age 14 to 20 needs

All the calcium a child to age 10 needs

Almost all the calcium a child age 10 to 18 needs

All the calcium elderly people need

Goat milk is lower in folic acid than cow or human milk. Therefore when fed to infants, goat's milk should always be supplemented with folic acid. Folic acid works with B vitamins, which help the body utilize protein and prevents anemia, poor growth and birth defects; it also supports the immune system (Sinn Rosalee, 2008).

Traditionally goat has served as source of livelihood and financial security to large section of society, mainly comprising of resource-poor people. In the present scenario of changing agro-climatic conditions, this 
small ruminant farm animal has tremendous potential to be projected as the "Future Animal" for rural and urban prosperity. The back yard goat rearing is steadily as the fast growing "'Livestock Industry" in the country. Goat husbandry in India is essentially an endeavor of millions of small holders who rear animals an 'Crop Residues' and 'Common Property Resources'. More often goats are reared for production of meat, but they also serve as ready source for milk to meat the family requirement (CIRG, Vision 2030).

Among all species of farm animals, goats have the widest ecological range and have been poor people's most reliable livelihood resource since their domestication during Neolithic Revolution about 10 millennia ago. Goats possess distinct social, economical advantages. They can be maintained on a limited area and can sustain on wide variety of vegetation in varied agro-climatic conditions. The goat milk is easily digestible due to smaller size of fat globules and serves as a ready source of family nutrition (CIRG).

Goat farming is significantly income generation and employment generation of rural masses. Goat, a small ruminant are generally reared in rain fed areas by landless or the resource poor farmers whose average agricultural holding is either very less (marginal and small farmers) or is not sufficient to devote for cultivation of crops (Kumar and Pant, 2003 and Singh et al.,2005). It is ideally suited for the poorest of the poor because of short gestation period, low risk capital investment and low cost of maintenance (Gopala et al., 2010).

Barbari is a beautiful medium size goat breed. Its white color and beautiful brown patches all around its body enhances its beauty and it looks like deer in appearance. The origin of barbari breed of goat is Berbera Somalia of East Africa. In India it is found in the state of
Uttar Pradesh and Punjab provinces specially in the north western India and Pakistan.

Barbari goats are also known for its early maturity and triple kidding is quite common in this breed. This is the medium size goat breed with short ear, twisted pointed horns with bulging eyes which increases its beauty naturally.

\section{Common barbari goat breed characteristic}

Medium size breed with an average weight of adult male is $30-37.5 \mathrm{~kg}$ and female 18 $22.6 \mathrm{~kg}$.

Barbari goats are very alert and attractive with short erect ears and short straight horns.

Raised for the meat production.

Very well adapted to the climate and mortality is less.

Conical teats, well adapted in stall feed condition.

\section{Milk yield in Barbari goat}

Though the milk yield is sufficient for feeding its kids.

Its average milk yield is 108 ltrs/lactation.

Lactation period is of 150 days.

Micro-minerals have a great impact on animal's productive and reproductive physiology and its imbalance causes various problems leading to lowered reproductive efficiency and resultant monetary lass. Health and production of livestock is greatly influenced by optimal level of these essential mineral (Sharma et al., 2009).

Adequate micro-minerals supplementation is required as most of the roughages, grains, concentrates are deficient in trace mineral elements, correcting an imbalance in mineral levels can improve reproductive performance and health with little additional cost (Kumar et al., 2011). 
Concept of area specific mineral supplement is a new approach of low input and high output for the end users. Therefore, there is an ample scope for exploiting the concept of area specific mineral supplementation for balancing the deficiency essential for the exploitation of optimum production potential of farm animals (Ghost et al., 2013).

Minerals should be given as an essential part of the ration as they contribute to the building of the skeleton physiological functions and production of milk. The mineral mixture may be included in the concentrate ration at the rate of 0.2 per cent.

Keeping these in view, the present study was undertaken to find the effect of area specific mineral supplementation on growth and reproductive performance of Goat.

\section{Materials and Methods}

\section{Selection of animals}

Goat of similar parity (30-30) (Local \& Barbari breed) were selected from the village Chiklana and Jhanjhakhedi of Ratlam district. Which control and experimental each had 30 animals. The animals were milked twice a day, during morning (6 AM) and evening (6 PM) after interval of 12 hours. In the control group 30 goats were provided a mixed diet of wheat straw and local mixed grasses (a mixture of leguminous and non leguminous species in varying proportions) roughages. In the experiment group 30 goats were offered mineral supplement along with the concentrate for a period of 13 weeks (90 days). Observations on milk production were recorded during the period as weekly.

$\mathrm{T}_{1}-$ Control

$\mathrm{T}_{2}$ - Treatment

\section{Composition of mineral supplement}

Area specific mineral mixture need to be formulated for different agro-climatic zones, based on a mineral mapping programme. Mineral mapping for various states has been completed by NDDB and developed area specific mineral mixture formulations for supplementing the ratio of dairy animals. Accounting to NDDB mineral mixture mapping, Bhopal Sahakari Dugdha Sangh \& Ujjain Sahakari Dugdha Sangh Madhya Pradesh have commenced and sale of area specific mineral mixture for growing and lactating animals. The mineral mixture used contained calcium, phosphorus, Zinc, Manganese, Copper, Silica and Fluoride (Table 2).

\section{Dosage of mineral supplement}

Since all the animals were not similar in milk production. Thus it is fixed quantity of mineral mixture supplement. 20g/animal/day was given in two equal doses of $10 \mathrm{~g}$ each at morning and evening. The mineral supplement was mixed with the concentrate supplement just before offering it to the goats during morning and evening. Daily milk production records of each goat were collected, tabulated and analyzed statistically.

\section{Concept of economics}

Value of gross output or gross income which was calculated from the formula (Quantity of milk $\times$ market price of milk)

Net profit or Net Income

Cost of feeding

B:C Ratio

\section{Results and Discussion}

\section{Increase in milk yield}

Data from table 5 reflected that $580.2 \mathrm{~g} /$ day of milk was produced by goats that were fed mineral mixture supplement as compared to 
427.3 g/day these goats which were fed concentrates only. The farmers usually rear their animals on grazing and supplementation of goats are completely stall-fed they should be given around 3-4 $\mathrm{kg}$ of green fodder, 1-2 $\mathrm{kg}$ of dry fodder and 200-250 $\mathrm{g}$ of concentrates. If the goats are partly stall-fed and party free range then $50 \%$ of the above quantities should be fed in the stall. Milk production was similar at the start of experiment, but with advancement of experiment, differences in milk production were observed which with increased gap among the groups (Table 4). Despite the differences among group's effects, significantly higher milk production was observed in animals supplemented with mineral mixture. So it has a significant effect on milk production per goat. The milk production was sustained at an higher level due to feeding of mineral supplement which otherwise would have been decreased due to higher demand of $\mathrm{Ca}$ and $\mathrm{P}$ for milk secretion. At times some increases and decreases was observed which was due to change in the major feed supplements, season, availability of drinking water and milker etc.
The average market price of milk was 20 $\mathrm{Rs} /$ Lit in treatment group and control group. So the profit was more in treatment group (Table 3).

The finding gets the support of the finding of Muktiani et al., (2008) who reported that the goat fed the ration supplemented with $\mathrm{Zn}$ and $\mathrm{Cr}$ produce higher milk yield (580.2 g/day) and better in milk fat production compared to those farmer practice.

The finding get the support of the finding of Bagum et al., (2010) who reported supplementation of calcium and Phosphorus in the dietary of buffaloes. Improved milk production milk fat and total solids contents, thus mineral supplementation is important to reduce economic losses due to mineral deficiencies and helpful in increasing income of farmers.

Similar finding have also been reported by Verma et al., (2009), Rohilla et al., (2007) and Saha and Kumar (2002) who observed significant effect of feed additives on milk production and fat $\%$.

Table.1 Goat population in India

\begin{tabular}{|l|c|c|}
\hline Small Ruminant & $\begin{array}{c}\text { Population as per 2012 } \\
\text { census }\end{array}$ & No. of farmers holders \\
\hline Goat & 135 million & 33.01 million \\
\hline
\end{tabular}

Production of Goat in India-FAO STAT

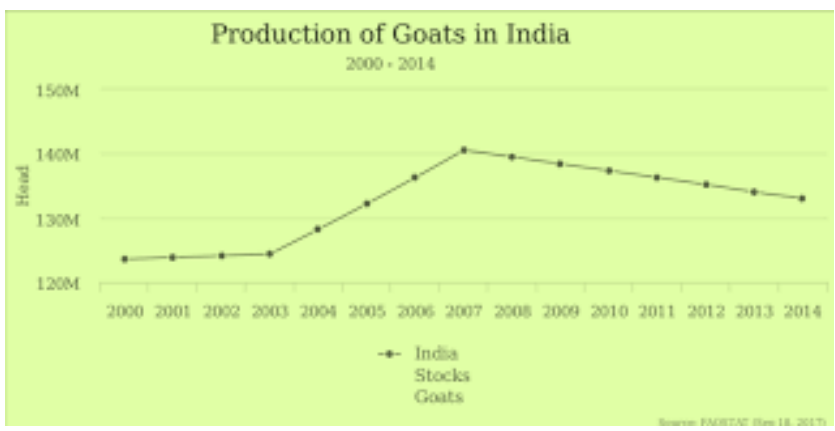


Table.2 Chemical composition of mineral supplement

\begin{tabular}{|c|c|c|}
\hline S.No & Minerals & Per centage \\
\hline $\mathbf{1}$ & Calcium & 26.50 \\
\hline $\mathbf{2}$ & Phosphorus & 10.00 \\
\hline $\mathbf{3}$ & Copper & 0.20 \\
\hline $\mathbf{4}$ & Zinc & 1.30 \\
\hline $\mathbf{5}$ & Manganese & 0.40 \\
\hline 6 & Fluoride & 0.06 \\
\hline 7 & Silica & 3.00 \\
\hline
\end{tabular}

Table.3 Economics performance

\begin{tabular}{|c|c|c|c|c|c|c|c|c|c|}
\hline \multirow[t]{3}{*}{ Year } & \multirow{3}{*}{$\begin{array}{c}\text { No. of } \\
\text { Animals }\end{array}$} & \multicolumn{8}{|c|}{ Economic performance } \\
\hline & & \multicolumn{2}{|c|}{$\begin{array}{l}\text { Cost of Rearing } \\
\text { (Rs.) }\end{array}$} & \multicolumn{2}{|c|}{$\begin{array}{c}\text { Gross Income } \\
\text { (Rs.) }\end{array}$} & \multicolumn{2}{|c|}{$\begin{array}{l}\text { Net Income } \\
\text { (Rs.) }\end{array}$} & \multicolumn{2}{|c|}{ B:CRatio } \\
\hline & & $\mathbf{F P}$ & $\mathbf{R P}$ & FP & $\mathbf{R P}$ & FP & RP & FP & $\mathbf{R P}$ \\
\hline $2015-16$ & 30 & 288 & 342 & 779.8 & 1026.7 & 491.8 & 684.7 & 2.70 & 3.00 \\
\hline 2016-17 & 30 & 294 & 348 & 764.6 & 1073.3 & 470.6 & 725.3 & 2.60 & 3.08 \\
\hline 2017-18 & 30 & 310 & 370 & 769.1 & 1044.4 & 459.1 & 674.4 & 2.48 & 2.82 \\
\hline Mean & 30 & 297.3 & 353.3 & 771.1 & 1048.1 & 473.8 & 694.8 & 2.59 & 2.96 \\
\hline
\end{tabular}

Table.4 Milk production in different groups (g/Week)

\begin{tabular}{|c|l|l|l|l|l|l|l|l|l|l|l|l|l|l|l|}
\hline Treatment & $\begin{array}{l}\text { Week/ } \\
\text { Year }\end{array}$ & $\mathbf{1}$ & $\mathbf{2}$ & $\mathbf{3}$ & $\mathbf{4}$ & $\mathbf{5}$ & $\mathbf{6}$ & $\mathbf{7}$ & $\mathbf{8}$ & $\mathbf{9}$ & $\mathbf{1 0}$ & $\mathbf{1 1}$ & $\mathbf{1 2}$ & $\mathbf{1 3}$ & Mean \\
\hline \multirow{3}{*}{$\mathrm{T}_{1}$} & $2015-16$ & 2800 & 2850 & 2940 & 3020 & 3090 & 3140 & 3180 & 3220 & 3140 & 3090 & 3050 & 2970 & 2940 & $\mathbf{3 0 3 3 . 0}$ \\
& $2016-17$ & 2790 & 2830 & 2850 & 2900 & 2970 & 3040 & 3090 & 3140 & 3100 & 3070 & 3010 & 2970 & 2900 & $\mathbf{2 9 7 3 . 8}$ \\
\hline \multirow{3}{*}{$\mathrm{T}_{2}$} & $2017-18$ & 2790 & 2820 & 2850 & 2900 & 2970 & 3000 & 3070 & 3120 & 3100 & 3060 & 3010 & 2990 & 2900 & $\mathbf{2 9 6 7 . 6}$ \\
\hline & $2015-16$ & 3800 & 3850 & 3910 & 3980 & 4030 & 4070 & 4120 & 4190 & 4130 & 4100 & 3930 & 3900 & 3900 & $\mathbf{3 9 9 3 . 0}$ \\
\hline & $2016-17$ & 3900 & 3950 & 4000 & 4170 & 4220 & 4290 & 4330 & 4390 & 4300 & 4250 & 4200 & 4170 & 4100 & $\mathbf{4 1 7 4 . 6}$ \\
\hline & $2017-18$ & 3830 & 3880 & 3920 & 3980 & 4010 & 4060 & 4100 & 4180 & 4130 & 4100 & 4080 & 4000 & 3970 & $\mathbf{4 0 1 8 . 4}$ \\
\hline
\end{tabular}

Table.5 Milk yield in different years

\begin{tabular}{|c|}
\hline year \\
\hline $2015-16$ \\
\hline $2016-17$ \\
\hline $2017-18$ \\
\hline Average \\
\hline
\end{tabular}

\begin{tabular}{|c|}
\hline No. of animals \\
\hline 30 \\
\hline 30 \\
\hline 30 \\
\hline $\mathbf{3 0}$ \\
\hline
\end{tabular}

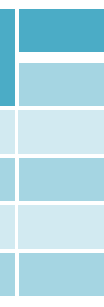

\begin{tabular}{|c|c|c|}
\hline \multicolumn{2}{|c|}{ Milk yield (g/day) } & $\begin{array}{c}\text { \% Increase in milk } \\
\text { yield }\end{array}$ \\
\hline $\mathbf{T}_{\mathbf{1}}$ & $\mathbf{T}_{\mathbf{2}}$ & 32.8 \\
\hline 433.2 & 570.4 & 36.1 \\
\hline 424.8 & 596.3 & 33.9 \\
\hline 423.9 & 574.0 & $\mathbf{3 4 . 3}$ \\
\hline $\mathbf{4 2 7 . 3}$ & $\mathbf{5 8 0 . 2}$ & \\
\hline
\end{tabular}

Cost Benefits analysis is clearly depicted in table 3 where the net profit was Rs. 694.8 in experimental group as compared to that of Rs. 473.8 in Control group. Therefore the B:C Ratio turned out to be 2.59 in Control and
2.96 in experimental group. The cost of rearing was Rs.353.3 in experimental group as compared to that of Rs. 297.3 in Control group. 
The study concluded that the balanced ration of goat is important for increase in milk yield, quality of milk and income/day. Thus, it is very essential to give mineral mixture every day and every farmer should note that mineral mixture is not a medicine but a very essential part of the animals' daily needs.

\section{References}

Barbari Goat Farming In India - Profitable Goat Breed For Commercial Farming https://www.expert-market.com/barbarigoat-farming-in-india-profitable-goatbreed-for-commercial-farming/

Dikshit, A.K., Reddy, B.S. and Manohar, N.S. (2012) Demographic changes in small ruminant population in India: Some inferences from different livestock regions. Indian Journal of Animal Sciences, 82(2): 187-193.

FAO (Food and Agriculture Organization of the United Nations) FAOSTAT (2015). Statistics Division, Rome. Available at: faostat3.fao.org.

Ghosh M.K., Chatterjee A., Mondal A., Das S.K. and Dutta T.K. (2013). Area specific mineral mixture (CALMINERS) for livestock in lower gangetic region of west Bengal.

GoI (Government of India) (2005-06). Agricultural Census. Department of Agriculture and Cooperation, Agriculture Census Division, Ministry of Agriculture, New Delhi.

GOI (2006). Basic Animal Husbandry Statistics (AHS-10). Ministry of Agriculture, Govt. of India.

Gopala G T, Veeranna K C and Shivakumar K R. 2010. Constraints in goat farming in Bidar district of Karnataka state. Research Journal of Animal Husbandry and Dairy Science 1(2):80-82.

Hegde, N.G. Livestock development for sustainable livelihood of small farmers. In souvenir of the $39^{\text {th }}$ Annual General
Meeting and $48^{\text {th }}$ National Symposium on 'Emergising Rural India- A Challenge to Livestock Industry. Compound livestock feed Manufactures Association of India (CLFMA), Manesar, Haryana, August 26: 50-63.

http://www.ndri.res.in/ndri/design,ERS.html. http://dahd.nic.in/sites/default/filess/NAP\%20 on\%20Goat.pdf

Begum, I.; A Azim; S Akhter; MI Anjum; M.Afzal,(2010).Mineral Dynamics of Blood and Milk in Dairy Buffaloes fed on Calcium and Phosphorus Supplementation. Pak Vet J, 30(2), 105109.

Kumar Shalander, Ramarao, C.A., Kareemulla K. and Venkatswarlu B. (2010). Role of Goats in Livelihood Security of Rural Poor in the Less Favoured Environments. Ind. Jn. Of Agri. Econ. Vol.65, No-4, Oct-Dec.

Kumar S and Pant K P. 2003. Development perspectives of goat rearing in India: Status, issues and strategies. Indian Journal of Agricultural Economics 58(4): 752-67.

Kumar, Shalander (2007a), "Commercial Goat Farming in India: An Emerging Agri-Business Opportunity", Agricultural Economics Research Review, Vol. 20 (Conference issue), pp. 503-520.

Kumar, Shalander (2007b), "Commercialization of Goat Farming and Marketing of Goat in India”, Final Project Report-ICAR Ad-hoc Research Scheme, CIRG, Makhdoom, Mathura.

Kumar S., Pandey A.K., Razzaque W.A.A. and Diwivedi D.K. (2011). Importance of micro minerals in reproductive performance of livestock. Vet. World. 4(5): 230-233

Muktiani A., Kusumanti E. and Harjanti D.W. (2018). Milk production of Ettawah Grade fed Diet Containing Different Protein and Energy Contents 
Supplemented with Organic Mineral and Grapes Oil. IOP Conf. Series: Earth and Environmental Science 119 (2018) 012051.

National Action Plan on Goat 2022. http://dahd.nic.in/sites/default/filess/NA P\%20on\%20Goat.pdf

Rohilla,P.P and Bohra, H.C. 2007: Effect of Nutrimix Feeding on milk yield of ewes and growth of Lambs. Indian Vet. J. 84: 1273-1275.

Sen, A.R., Santra, A. and Karim, S.A. (2004). Carcass yield, composition and meat quality attributes of sheep and goat under semi arid conditions. Meat Sci., 66(4): 757-763.

Saha S.K. and Kumar, C.K (2002) Effect of Antibiotics on in Vitro Dry Matter and Neutral Detergent Fiber Digestibility and NH3-N Concentration in Buffalo. Indian Vet J. 579-582.

Sharma M.C., Tiwari R. and Kumar P. (2009). Area specific mineral mixture: need and importance. Vet. Commun., 4:3-8

Singh, S.K. (2004). Security system for goat germ plasm in India. Proceeding of Seminar on Goat Genome. CIRG, Mathura. 87pp.

Singh V K, Suresh A, Gupta D C and Jakhmola R C. (2005). Common property resources of rural livelihood and small ruminants in India: A review. Indian Journal of Animal Science, 75(8): 1027-36.

Singh, M.K., Dixit, A.K., Roy, A.K. and Singh, S.K. (2013) Goat rearing: A pathway for sustainable livelihood security in Bundelkhand region. Agricultural Economics Research Review, 26 (Conference Number): 7988.

Sinn Rosalee, Paul Rudenberg and barbara Curler (2008) New Revised Edition, Raising Goats for Milk and Meat, Heifer International.

Tanwar P S. 2011. Constraints perceived by goat keepers in adoption of goat husbandry practices in semi-arid Rajasthan. Journal of Community Mobilization and Sustainable Development 6(1):108-11.

Vision 2030, Central Institute for Research on Goats, Makhdoom, Farah-241122, Mathura (U.P.) India.www.cirg.res.in

Verma, R.K., Kumar P.A. Adil and Arya, G.K., 2009. Effect of Feed Supplement on Milk Production, Fat \% Total Serum Protein and Minerals in Lactating Buffalo. Veterinary World, 2(5): 193194.

\section{How to cite this article:}

Barkha Sharma, Jagdish Patidar, D.R. Pachauri and Sarvesh Tripathy. 2018. Goat Rearing: A Pathway for Livelihood Security of Farm Women. Int.J.Curr.Microbiol.App.Sci. 7(12): 439446. doi: https://doi.org/10.20546/ijcmas.2018.712.055 